\title{
Trening autogenny i audiowizualna relaksacja (tzw. trening alpha) jako narzędzia odnowy psychosomatycz- nej w sporcie i rehabilitacji*1/
}

\author{
Mirosław Mikicin, Ewa Mikicin \\ Międzywydziałowe Laboratorium Neuropsychofizjologii, Akademia Wychowania \\ Fizycznego w Warszawie \\ Szpital Dziecięcy im. Prof. dr J. Bogdanowicza, Warszawa
}

\section{Streszczenie}

Doświadczanie tzw. stanu alfa (przejawiającego się w dominującej czynności bioelektrycznej alpha) jest dla sportowca niezastapionym środkiem regeneracji oraz sposobem na zmniejszanie poziomu napięcia mięśni podczas ćwiczeń rehabilitacyjnych. Osiaganie wysokiego poziomu tego stanu stanowi podstawę do dalszej pracy neuropsychofizjologicznej sportowca związanej ze stymulacją czynności bioelektrycznej mózgu podczas startu oraz w procesie rehabilitacji po doznaniu urazu fizycznego.

Cel pracy: Określenie wpływu audiowizualnej relaksacji i treningu autogennego na generowanie fal mózgowych alpha (7-12 Hz.).

Materiał: W badaniach uczestniczą 15 letni pływacy (28 osób). W grupie eksperymentalnej (14 osób) stosowano przez $10 \mathrm{~m}$-cy audiowizualną relaksację i trening autogenny.

Metody: Freez-Framer emwave PC (stress relief system) oraz EEG.

Wyniki: Osoby badane wykazują progresję w poziomie relaksu, amplitudzie fal mózgowych alpha oraz wykonywaniu zadań sportowych. Świadczy to o pozytywnym wpływie systematycznego stosowania relaksacji audiowizualnej i treningu autogennego na zachowanie. Progresywna zmiana w organizmie sportowca znajduje odzwierciedlenie w obiektywnych wskaźnikach relaksu oraz elektroencefalografii mózgu. Należy stosować trening odnowy psychosomatycznej po każdym treningu sportowym oraz ćwiczeniach rehabilitacyjnych.

Słowa kluczowe:

Key words: fale mózgowe, audiowizualna relaksacja mózgu, trening autogenny, EEG, odnowa psychosomatyczna, stan alfa

Abstract: Experience alfa state is indispensable to sportsmen for energy recovery and becomes a way to reduce the level of stress. Reaching high level of alpha state is essential for further sportsman's mental work connected with stimulation of development during competitions.

The purpose of the study: Evaluation of the effect of audiovisual brain relaxation and autogenic training on generation of alpha waves in sportsmen.

Material: 15 -year old swimmers (28 persons) were selected for the investigations. In experimental group (14 persons), audiovisual brain relaxation and autogenic training were used for 10 months.

Methods: Freeze-Framer emwave PC (stress relief system) and EEG.

Results: The investigated group showed progression in relaxation level, alpha waves amplitudes and performance of sport-related tasks. This proves positive impact of regular audiovisual brain relaxation and autogenic training on behavior. Progressive changes in sportsman's body are reflected in objective relaxation indexes and brain electroencephalography. Psychosomatic recovery training should be therefore applied after each sport activity.

brain waves, audiovisual brain relaxation, autogenic training, EEG, psychosomatic recovery, Alfa state.

*/Temat zrealizowano w ramach projektu badawczego AWF Warszawa, BW I/35 


\section{Wprowadzenie}

W tzw. stanie alfa (przejawiającym się w dominującej czynności bioelektrycznej alpha) znaj-dujemy się zawsze na krótko przed zaśnięciem i zaraz po przebudzeniu, a także czasem w chwilach głębokiego zamyślenia lub skupienia [1]. Występuje wówczas przewaga fal alpha w mózgu, czyli czynności bioelektrycznej o częstotliwości 7 -12 Hz. W rzeczywistości jednak nie ma takich momentów, w których mózg generuje tylko fale alpha. Dlatego możemy jedynie mówić o przewadze (dominacji) fal alpha w mózgu. Fale alpha rejestrowane są głównie w okolicy potyliczno-ciemieniowej i charakteryzują się zmienną amplitudą. Są one wyrazem synchronizacji czynności wielu jednostek dendrytycznych [2] i pojawiają się w stanie czuwa-nia z relaksem. Występują zwykle przy zamkniętych oczach. Znikają podczas wysiłku np. wykonywaniu ćwiczeń albo przy otwarciu oczu i zadziałaniu światła. Tzw. stan alfa jest doskonałym stanem do odpoczynku i regeneracji organizmu. Możemy dzięki tzw. treningowi alpha wpływać na własne zdrowie i samopoczucie, pozbywać się zahamowań, wzmacniać wiarę w siebie, łatwiej rozwiązywać problemy a co najważniejsze w sporcie, możemy ,pro-gramować podświadomość” na osiąganie sukcesów. Hatwield [3] badając częstotliwość alpha $(7-12 \mathrm{~Hz})$ u wykwalifikowanych snajperów podobnie jak Crews i Landers [4] badając golfi-stów oraz Landers i inni [5] w łucznictwie stwierdzili, że po treningu alpha zwiększa się wy-dajność. Strzelcy, łucznicy czy golfiści, wymagają podwyższenia amplitudy fal alpha dla po-prawy spokoju umysłu do lepszej celności, natomiast w innych dyscyplinach sportu jak gim-nastyka, jazda na nartach, jazda na łyżwach, hokej, snowboard, sporty walki, koszykówka, trening taki ma wpływ na poprawę równowagi fizycznej [6]. Wzorzec aktywności mózgu tych sportowców związany jest prawdopodobnie ze zmiennością (lub stałością) tempa pracy oraz dokładnością i starannością wykonania zadania sportowego. Systematycznie analizowano skuteczność treningu alpha w odniesieniu do rehabilitacji $[7,8,9]$. W szczególności, stosowany jest w rehabilitacji zaburzeń psychomotorycznych jako rozluźnienie mięśni, po którym sygnał sprzężenia zwrotnego wspomaga aktywność ruchową [10]. Badano czy trening alpha jest skuteczny w zakresie poprawy wydajności ruchu po interwencji chirurgicznej [11] oraz z porażeniem mózgowym u dzieci [12], jednak nie znaleziono na to wystarczających dowodów. Nie wiadomo również czy istnieje możliwość pozytywnego stosowania treningu alpha u osób starszych [13], ze względu na współwystępowanie innych zaburzeń zdrowotnych, takich jak zaburzenia układu mieśniowo-szkieletowego i problemy sercowo-naczyniowe, spadek funkcji czuciowych lub zdolności poznawczych [14]. Przy wyłączeniu tych uwarunkowań i trudności w przetwarzaniu sygnałów EEG, istnieje potrzeba oceny skuteczności tego treningu w związku z zastosowaniem go dla poprawy równowagi i mobilności osób starszych $[13,15,16]$. Za-stosowane przez innych autorów w badaniach różne kryteria oparte na programach dla ćwi-czenia równowagi [6] i mobilności [17] potwierdziły jego skuteczność.

Interesujące dla neuropsychologa jest pytanie:, jakie zachodzą zmiany w potencjałach czyn-nościowych mózgu, jaki mają one wpływ na zachowanie [18] oraz czy sportowiec $\mathrm{w}$ warun-kach treningowych, startowych oraz $\mathrm{w}$ procesie rehabilitacji jest w stanie osiagnać optymalny poziom relaksu mięśniowego [19]. W badaniach naukowych wykazano, że zarówno często-tliwość fal mózgowych jak i ich amplituda nie jest ściśle stała i zależy od zadania, jakie mózg wykonuje. Zastosowano audiowizualną relaksację i trening autogenny. Podczas relaksacji audiowizualnej stwierdzono, że podawane bodźce wzrokowe i słuchowe wytwarzają zmiany w dominującej częstotliwości fal mózgowych. Mózg jest bardzo czuły na bodźce i reaguje $\mathrm{w}$ ten sposób, że potrafi do nich dostosować się. Dochodzi wówczas do zwiększenia kreatywności i wyobraźni, polepszenia pamięci i koncentracji uwagi, relaksu, polepszenia pracy układu odpornościowego, lepszej samokontroli emocjonalnej i wielu innych zmian. Zastosowano program „Najgłębsza relaksacja”, który przeprowadza ćwiczącego najpierw ze stanu czuwania, poprzez głęboką relaksację, aż w końcu z powrotem w stan czuwania, aby mógł natychmiast włączyć się do wykonywania jakiejkolwiek czynności. Ponieważ zmiany potencjałów czynnościowych mózgu idą $\mathrm{w}$ parze $\mathrm{z}$ optymalnym poziomem relaksu mięśniowego, włączono dodatkowo trening autogenny Schultza [19], w którym podstawową rolę odgrywa autosugestia. Celem takiego zabiegu było uzyskiwanie tego, co relaksacji towarzyszy, to jest: we-wnętrznego spokoju, wewnętrznej pogody ducha jako reakcji demobilizacyjnej, będącej swo-istym antidotum na reakcje mobilizacyjne związane $\mathrm{z}$ aktywnością sportową i rehabilitacja. Zdaniem Schultza [19], technika ta określona może być mianem psychicznej gimnastyki. Za-kłada się, że audiowizualna relaksacja $\mathrm{w}$ połączeniu $\mathrm{z}$ treningiem autogennym oddziałuje na cały organizm, bowiem stymulowany właściwie mózg automatycznie wysyła informacje po-wodujące adekwatną reakcję całego organizmu. Wówczas sugestie autogenne ukierunkowują cały proces na uzyskanie demobilizacji.

Postawiono następującą hipotezę: Po zastosowaniu treningu autogennego i audiowizualnej relaksacji następuje zmiana w organizmie człowieka, co znajduje odzwierciedlenie we wskaźnikach relaksu oraz poziomie amplitudy fal mózgowych alpha.

\section{Metoda i materiał}

Badania miały charakter eksperymentalny, zatem obserwacji poddano zmienne zależne (relaks i fale mózgowe alpha), zmienne niezależne (trening autogenny i audiowizualny) oraz zmienne pośredniczące (wysiłek i zadania sportowe). Do pomiaru poziomu relaksu i fal mózgowych alpha zastosowano narzędzia:

Freez-Framer emwave PC (stress relief system), do kontroli stan relaksu. To metoda GSRBio-feedbeck (biologiczne sprzężenie zwrotne), metoda, która w swojej istocie bada proces bycia świadomym istnienia wewnętrznych funkcji organizmu oraz kontroli nad nimi [20,21]. Po-przez monitorowanie ich sygnałów w czasie rzeczywistym, podczas stosowania biologicznego sprzężenia zwrotnego otrzymujemy zwrotnie bio-sygnały z organizmu, takie jak poziom napięcia i rozluźnienia oraz częstotliwość uderzeń serca w sposób świadomie odczuwalny. Czułe instrumenty elektroniczne mierzą zmiany wyrażane przez skórę w formie potencjałów elektrycznych. Sygnały te są wzmacniane i opracowywane przez komputer, 
a rezultaty poka-zywane w formie wykresów i wartości liczbowych. Wskaźnikiem progresji stanu relaksu mię-śni jest różnica w poziomie napięcia i rozluźnienia, przeciętnym tempie uderzeń serca na mi-nutę (Average Heart Rate in Beats per minute BPM), i ogólne pogodzenie się ze sobą (Cohe-rence Ratio Screen - \%) w 7 minutowych badaniach kontrolnych. Metoda ta może również służyć do treningu relaksu.

EEG - elektroencefalografia mózgu. Metoda diagnostyczna używana w medycynie, którą tak przed jak i po 10 miesiącach audiowizualnej relaksacji mózgu oraz treningu autogennego, zastosowano do diagnozy dotyczącej częstotliwości i amplitudy fal alpha. EEG - to zapis (w postaci wykresu oraz wartości liczbowych), potencjałów czynnościowych mózgu odbieranych podczas wykonywania elektroencefalografii. Elektroencefalograf to urządzenie, wyposażone w układ elektrod (10 lub 20) umieszczonych w standardowych miejscach, odbierających sy-gnały z powierzchni głowy. Tradycyjnie EEG to: 1) badanie spontanicznej czynności bioelek-trycznej mózgu oraz 2) badanie potencjałów wywołanych. Pierwsze badanie dotyczy zmian potencjału elektrycznego generowanego przez duże populacje komórek mózgu, natomiast przy pomocy drugiego analizowane zmiany potencjału pozostają w ścisłym związku czasowym z określonymi zdarzeniami, takimi jak: ekspozycja bodźca, aktywność motoryczna czy rozwią-zywanie zadania (będzie wykorzystane w późniejszych badaniach).

W badaniach uczestniczyło 28 pływaków (piętnastoletnich juniorów). Grupę badaną tworzyli pływacy (14 osób), którzy uczestniczyli przez 10 m-cy (każdego dnia) w treningu autogennym (grupowo przez 30 minut) i w treningu audiowizualnej relaksacji mózgu (indywidualnie w domu po popołudniowych zajęciach 35 minutowy program relaksacyjny AVS). Osoby z grupy kontrolnej to pływacy (14 osób z tej samej sekcji pływackiej), którzy nie uczestniczyli $\mathrm{w}$ treningach relaksacyjnych. Badania prowadzono od lutego do listopada. Próby początkowe i końcowe wykonano podczas zawodów sportowych a pomiędzy nimi wykonano pięć prób kontrolnych podczas treningów sportowych. Pomiędzy stanem wyjściowym (pierwsza próba) a efektem końcowym (ostatnia próba) kontrolowano warunki mające wpływ na obserwowane reakcje organizmu sportowców. Wszystkie warunki i okoliczności mające wpływ na badany stan aktywności mózgu ( np. wysiłek, emocje, pogoda, zadania sportowe) były jednakowe dla wszystkich osób. Jednak nie można, jednakowo dla wszystkich osób, ocenić snu i odpoczynku, ponieważ relaksacja audiowizualna $\mathrm{i}$ autogenna pozwala ćwiczącemu jakościowo lepiej doświadczać tych stanów.

\section{Wyniki}

Symptomami neuropsychofizjologicznych zmian u osób badanych, u których zastosowano trening autogenny z audiowizualną relaksacją mogą być wskaźniki napięcia i rozluźnienia (stress relief system), tj: poziomu pobudzenia, przeciętnego tempa uderzeń serca, (Avarage Heart Rate BPM), oraz poziom relaksu mięśni (Coherence Ratio Screen \%). Na rycinie 1 przedstawiono zmianę w poziomie relaksu i pobudzenia podczas pierwszego treningu $\mathrm{z}$ zasto-sowaniem audiowizualnej relaksacji mózgu. Poziom relaksu z $31 \%$ podwyższył się do $73 \%$ natomiast pobudzenie spadło z 78 do 62 (Avarage Heart Rate BPM). Jednocześnie spadły wskaźniki napięcia z $36 \%$ do $8 \%$.
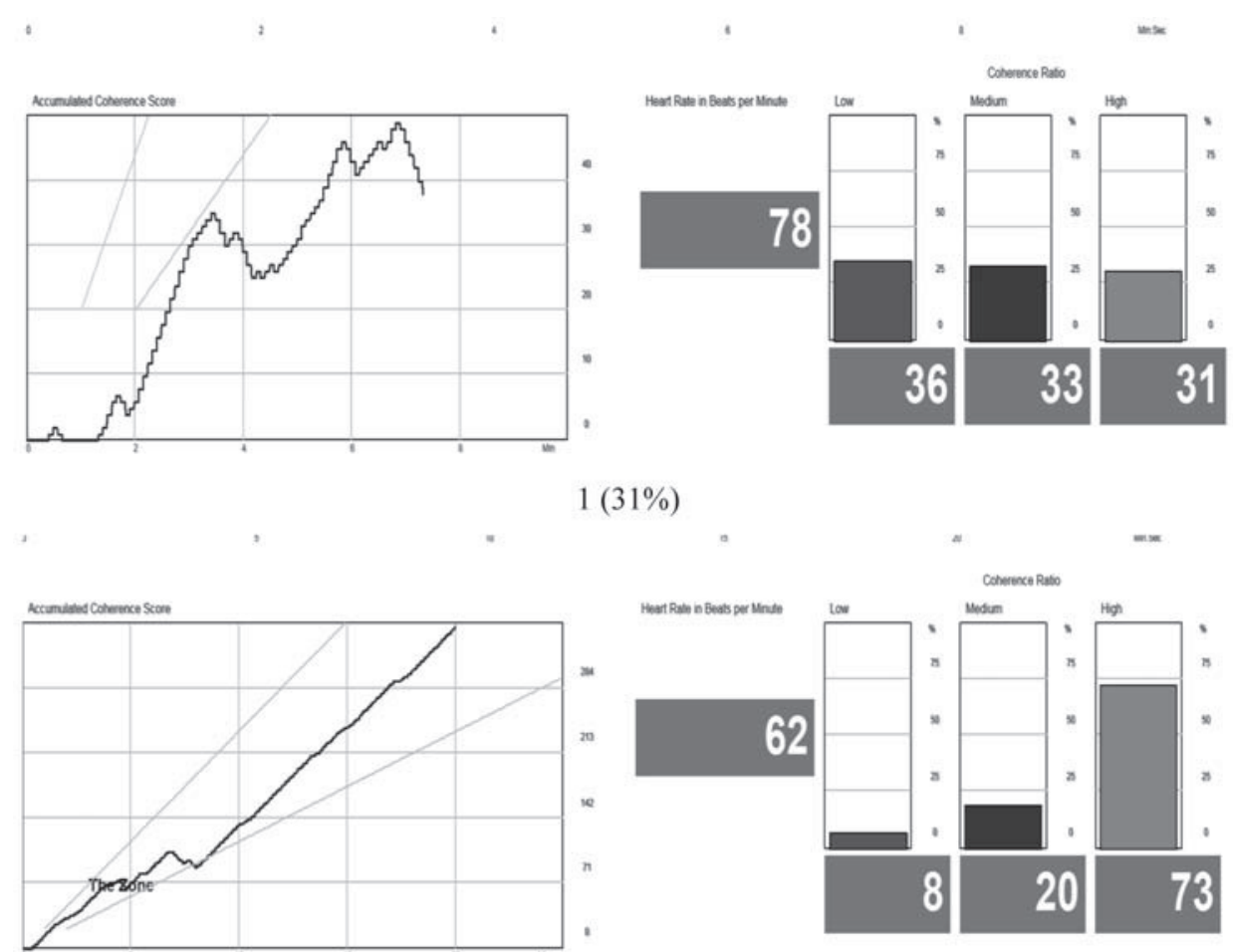

$2(73 \%)$

Ryc.1 Progresja relaksu 1 (31\%) i 2 (73\%) i obniżenie pobudzenia (78 i 62 BPM) podczas 35 minutowego treningu audiowizualnej relaksacji mózgu (Freez-Framer) 
W badaniu początkowym ujawniono zbliżony poziom relaksu w obydwu grupach (ekspery-mentalnej i kontrolnej), natomiast w kolejnych badaniach kontrolnych (tabela 1)

różnica ta powiększa się na korzyść osób, które stosowały trening audiowizualny i autogenny.

Tab. 1 Poziom relaksu ( \%) osób badanych i grupy kontrolnej w okresie 10 miesięcy (n=28)

\begin{tabular}{|c|c|c|c|c|c|c|c|}
\hline & 1 & 2 & 3 & 4 & 5 & 6 & 7 \\
\hline Eksp. \% N=14 & 30,2 & 50,1 & 64,4 & 50,2 & 62,2 & 90,2 & 100 \\
\hline Kontr.\% N=14 & 32,4 & 30,3 & 34,6 & 31,6 & 30,1 & 35,7 & 32,7 \\
\hline
\end{tabular}

Osoby badane wykazują progresję $\mathrm{w}$ poziomie relaksu (rycina 2), osiagając w siódmym bada-niu końcowym (po 10 miesiącach) nawet $100 \%$ (7). Świadczy to o pozytywnym wpływie systematycznego stosowania relaksacji audiowizualnej i treningu autogennego.

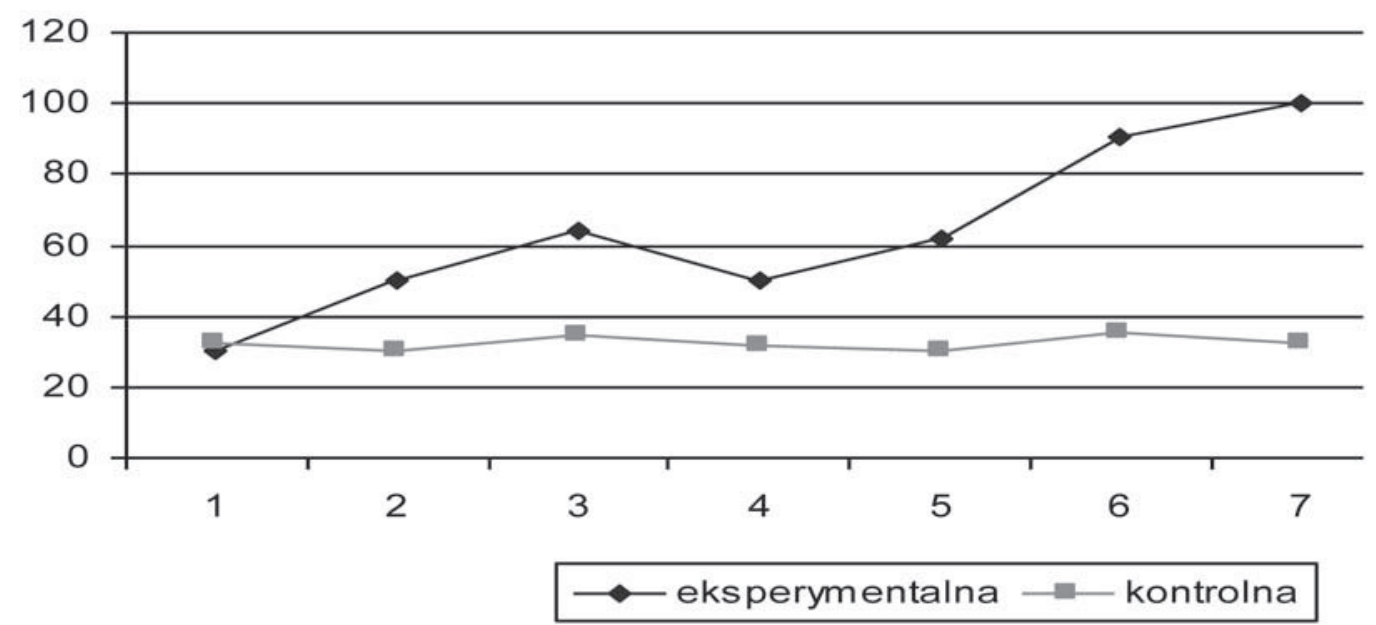

Ryc. 2. Poziom relaksu osób badanych (b) i grupy kontrolnej (k) w okresie 10 miesięcy (n=28) - Freez-Framer (stress relief system)

Pokazano (ryc.3) progresję spadku pobudzenia u osób, które stosowały trening autogenny i audiowizualną relaksację. Z każdym miesiącem serce pracuje spokojniej. Przyspieszenie tempa uderzeń serca (4) związane jest prawdopodobnie z Mistrzostwami Polski, podczas których to badanie kontrolne przeprowadzono. Zastosowano wówczas progra- my stymulujące aktywność mózgu w okresie dwóch tygodni przed mistrzostwami, co prawdopodobnie spowodowało wzrost pobudzenia (ryc.3) i spadek poziomu relaksu do 55\% (ryc. 2). Kluczem do tego jest zaangażowanie, pozwalające na harmonijną aktywność mózgu i mięśni.

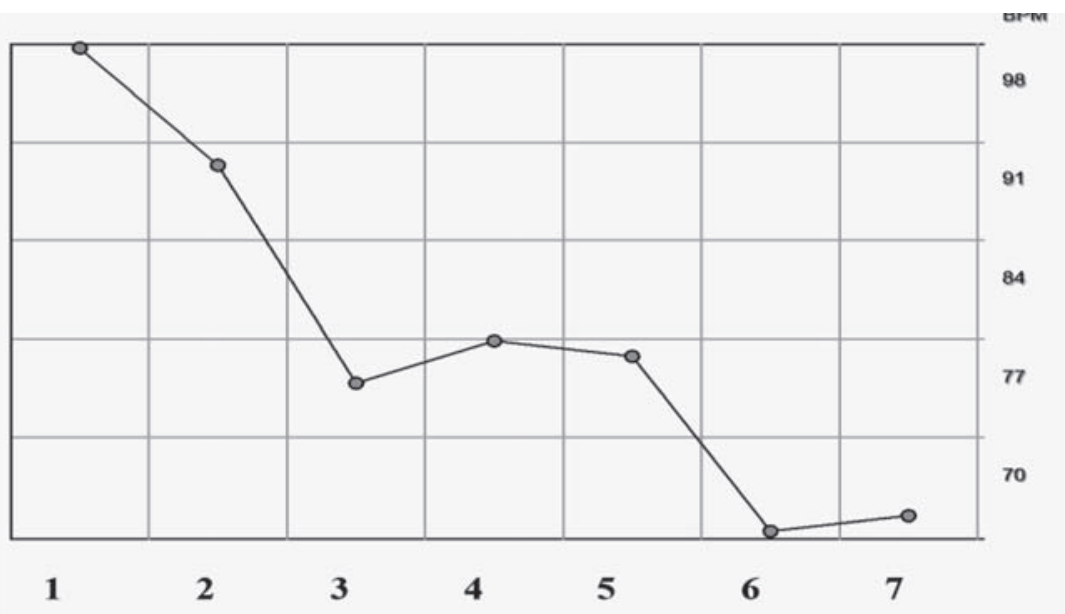

Ryc. 3. Przeciętne tempo uderzeń serca na minutę (Average Heart Rate in Beats per minute BPM) - Freez-Framer (stress relief system) w okresie 10 miesięcy. 
Przeciętne tempo uderzeń serca na minutę, osób w grupie kontrolnej, osiaga wysokie 85 do ponad 110 BPM. Można przypuszczać, że w okresie 10 miesięcy w badaniach kontrolnych poziom pobudzenia zmieniał się $\mathrm{w}$ związku $\mathrm{z}$ bieżąca sytuacją. Również zauważono wzrost wartości pobudzenia przed zbliżającymi się Mistrzostwami Polski. U osób z grupy kontrolnej poziom relaksu najpierw spada, następnie rośnie najwyżej do $80 \%$, po czym znów spada do wartości początkowej. Mając na uwadze trening sportowy, któremu są codziennie poddawane (w wymiarze takim jak osoby badane), można przypuszczać, że ich aktywność sportowa przebiega często w stanie chronicznego napięcia. W efekcie tego rozwój tych sportowców nie może przebiegać optymalnie do ich możliwości i wkładu pracy. Ponadto zarówno trening jak i rywalizacja sportowa w takim stanie staje się bardzo utrudniona.

Prawdopodobnie dzięki relaksacji oraz zdolności do redukcji zakłócających bodźców ze-wnętrznych i wewnętrznych badani sportowcy potrafią również głębiej „wejść w tzw. stan alfa". Stan ten u osób badanych wyrażony poziomem amplitudy fal alpha (oczy otwarte) różni się istotnie $(\mathrm{p}<, 0000001) \mathrm{w}$ badaniu początkowym (alpha_1) i badaniu końcowym (alpha 2). Nastapił wzrost amplitudy fal alpha, co świadczy o tym, że w czasie 10 miesięcznych treningów audiowizualnych mózg „uczył się” generowania potencjałów w paśmie $7-12 \mathrm{~Hz}$.

Tab. 2. Amplituda fal mózgowych alpha osób badanych początkowa (alpha_1) i końcowa (alpha_2) w badaniu EEG. $(n=14)$

\begin{tabular}{|c|c|c|c|c|}
\hline zmienne & $\mathrm{M}$ & $\mathrm{SD}$ & $\mathrm{t}$ & $\mathrm{p}$ \\
\hline alpha_1 & 8,69231 & 1,031553 & & \multirow{2}{*}{$-10,1559$} \\
\cline { 1 - 2 } alpha_2 & 10,15385 &, 987096 & \\
\hline
\end{tabular}

Na wykresie sekwencyjnym (ryc. 4) przedstawiono progresję poziomu amplitudy alpha w centralnej okolicy mózgu (oczy otwarte) u osób badanych.

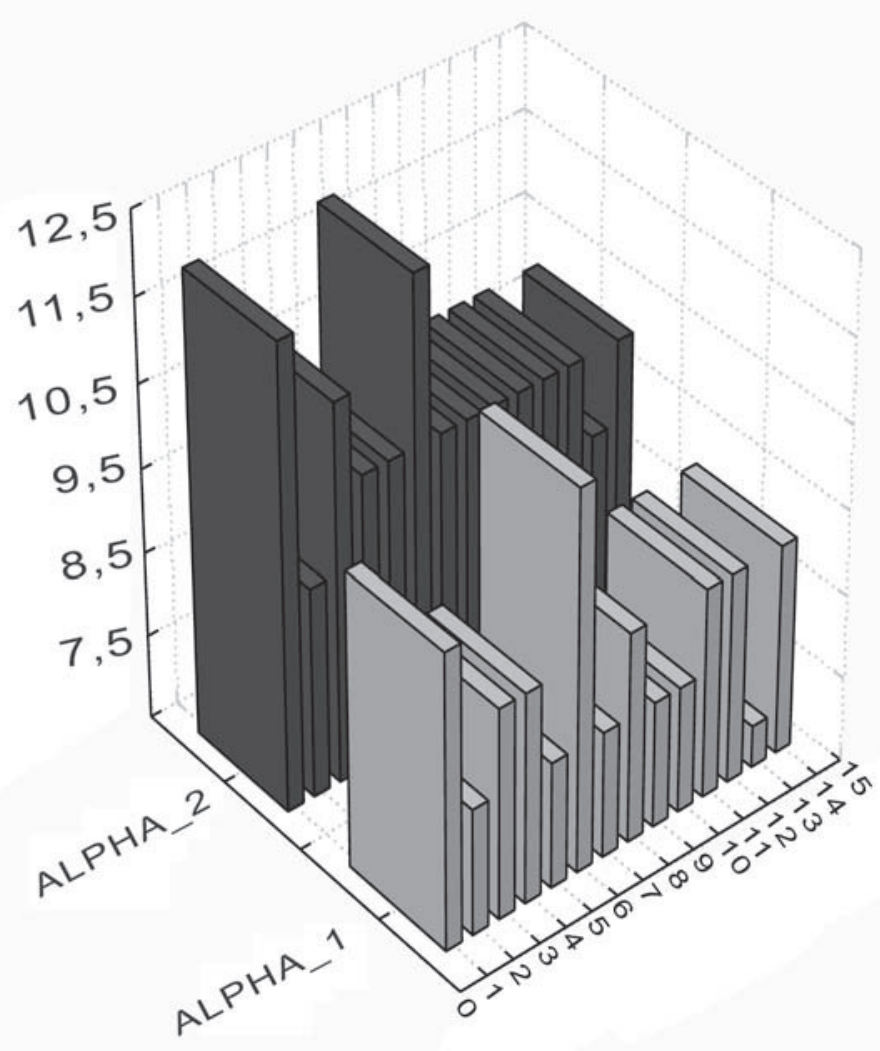

Ryc. 4 Wykres sekwencyjny czynności bioelektrycznej alpha, osób badanych (n=14) w początkowym (alpha 1) i końcowym (alpha 2) badaniu EEG (oczy otwarte)

\section{Dyskusja}

Długotrwały i często powtarzający się stan zmęczenia, rozdrażnienia czy napięcia hamuje postęp zarówno w sporcie jak i w rehabilitacji. W takim stanie w mniejszym lub większym stopniu, sportowiec kończy każdy trening sportowy (zwłaszcza przy dużych obciążeniach). Oznacza to, że w krótkim czasie może dojść do przeciążenia organizmu. Wówczas można spodziewać się zniechęcenia do aktywności sportowej a następnie, jeśli przeciążenie będzie narastać, może dochodzić do kontuzji. Ale przecież napięcie narastające podczas treningu sportowego i stan mobilizacji potrzebny do wykonania zadań [22] nie obniżą się samoczynnie w ciagu krótkiego czasu pomiędzy treningami do poziomu, który pozwoliłby na głęboki od-poczynek. Dochodzi również do braku synchronizacji w czynności bioelektrycznej obydwu półkul mózgowych [23,24] 
co w konsekwencji przejawia się w braku zrównoważenia emo-cjonalnego oraz zmniejszenia wydajności mózgu. Dzieje się tak, ponieważ występuje deficyt tzw. neurotransmiterów (przekaźników nerwowych). Przewodzenie pomiędzy komórkami mózgowymi następuje dzięki procesom biochemicznym właśnie za ich pośrednictwem [25].

W badaniach wykazano, że zastosowana metoda łącząca relaksację audiowizualna i trening autogenny, z punktu widzenia szybkości i skuteczności jest bardzo efektywną metodą odnowy psychosomatycznej w sporcie i rehabilitacji. Już po jednym 35 minutowym treningu relaksacyjnym ćwiczący odczuwają dobre samopoczucie i pozytywne emocje. Audiowizualna relaksacja $\mathrm{w}$ połączeniu $\mathrm{z}$ treningiem autogennym oddziaływuje na cały organizm, bowiem stymulowana właściwie aktywność mózgu powoduje adekwatną reakcję całego organizmu a sugestie autogenne ukierunkowują cały proces na uzyskanie demobilizacji. Wyniki te wskazują, że osoby z grupy eksperymentalnej lepiej radzą sobie w różnych okolicznościach (zmęczenie podczas treningu, wysokie pobudzenie podczas zawodów sportowych) niż osoby z grupy kontrolnej. Młodzi pływacy, którzy stosowali trening autogenny i audiowizualną relaksację lepiej wykonują zadania sportowe niż ci, którzy nie stosowali tych zabiegów odnowy psychosomatycznej.

Zatem zarówno trening sportowca jak i ćwiczenia rehabilitacyjne powinny kończyć się relak-sacją, aż do momentu głębokiego odpoczynku. Należy po każdym treningu sportowym i rehabilitacyjnym stosować trening odnowy psychosomatycznej, w którym sportowiec może osiągnąć stan demobilizacji całego organizmu. Wówczas, kiedy w mózgu następuje zamiana dominujących szybkich fal beta na wolne fale alpha, kiedy mięśnie znajdują się w „bezwła-dzie” i pojawia się ciepło rozszerzające naczynia krwionośne, mięśnie sportowca oczyszczają się z ubocznych produktów przemiany materii nagromadzonych podczas treningu sportowego, następuje głęboki stan relaksu (rozluźnienie, odprężenie, zmniejszenie stanu mobilizacji orga-nizmu) [19]. Sportowiec doświadcza tzw. stanu alfa, który przejawia się bierną uwaga, pozytywnym myśleniem, uwolnieniem od stresu, spadkiem koncentracji, uspokojeniem we-wnętrznym, obniżeniem czynności mózgowych. Charakteryzuje on, zatem wewnętrzne po-ziomy aktywności umysłowej odpowiedzialne za spokój i odpoczynek. Taki odpoczynek pozwoli w kolejnym treningu sportowym i ćwiczeniach rehabilitacyjnych na aktywność dająca radość, satysfakcję i postęp [26]. Dlatego w pierwszym etapie neuropsychostymulacji [27] należy „nauczyć mózg” sportowca osiągania wysokiego poziomu tzw. stanu alfa jako reakcji demobilizacyjnej po treningu sportowym. Potencjalne korzyści z treningu alpha płyną również z domniemanego oddziaływania na układ limbiczny emocji $[28,29,30]$, prawdopodobnie odpowiedzialny za poziom stresu.

\section{Piśmiennictwo}

1. Jodzio K. Neuronalny świat umysłu. Kraków: Oficyna Wydawnicza Impuls; 2005.

2. Singer W. Synchronization neuronale et représentations mentales. Pour la science, 2002; 302: 74-79.
3. Hatfield BD. The role of the left temporal region during the cognitive motor demands of shooting in skilled marksmen. Biological Psychology 2001; 58 (3): 263-277.

4. Crews DJ, Landers DM. Electroencephalographic measures of attentional patterns prior to the golf putt. Medical Science \& Sports Exercise 1993; 25 (1): 116-126.

5. Landers DM, Han M, Salazar W, Petruzzello SJ, Kubitz KA, Gannon TL. Effect of learning on electroencephalographic and electrocardiographic patterns in novice arc-hers. International Journal of Sports Psychology 1994; (22): 56-71.

6. Hammond DC. Neurofeedback for the Enhancement of Athletic Performance and Physical Balance. The Journal of the American Board of Sport Psychology 2007; Vol. 1: 77-86.

7. Barclay-Goddard R, Stevenson T, Poluha W, Moffatt M, Taback S. Force platform feedback for standing balance training after stroke. Cochrane Database Syst. Rev. 2004.

8. Kirtley E, Thornton Ć, Dennis P. Efficacy of Traumatic Brain Injury Rehabilitation: Interventions of QEEG-guided Biofeedback. Computers, Strategies and Medications. Springer Science Media; LLC 2008.

9. Kirtley E, Thornton Ć, Dennis P. Traumatic Brain Injury Rehabilitation: QEEG Bio-feedback. Treatment Protocols. Springer Science Media; LLC 2009.

10. Egner T, Gruzelier JH. Learned self-regulation of EEG frequency components affects attention and event-related brain potentials in humans. NeuroReport 2001; (12): :4155-4159.

11. Zijlstra A, Mancini M, Chiari L, Zijlstra W. Biofeedback for training balance and mo-bility tasks in older populations: a systematic review. Journal of NeuroEngineering and Rehabilitation 2010; 7;1;58 http: //www.jneuroengrehab. com/content.

12. Bobrowski R, Rozkres-Bobrowska M, Sobaniec P. Ocena wpływu EEG Biofeedback na obraz EEG oraz stan kliniczny u dzieci z mózgowym porażeniem dziecięcym. Neu-rologia Dziecięca 2007; Vol. 16: 83.

13. Horlings C, Engelen B, Allum J, Bloem B. A weak balance: thecontribution of muscle weakness to postural instability and falls. Nat Clin Pract Neurol. 2008; (4): 504-515.

14. De Bruin ED, Swanenburg J, Betschon E, Murer K. A randomised controlled trial in-vestigating motor skill training as a function of attentional focus in old age. BMC Geriatrics 2009: 9-15.

15. Heiden E, Lajoie Y. Games-based biofeedback training and the attentional demands of balance in older adults. Aging Clin Exp Res. 2009.

16. Howe TE, Rochester L, Jackson A, Banks PM, Blair VA. Exercise for improving bal-ance in older people. Cochrane Database Syst. Rev. 2007; CD004963.

17. Eser F, Yavuzer G, Karakus D, Karaoglan B. The effect of balance training on motor recovery and ambulation after stroke: a randomized controlled trial. Eur J Phys Rehabil. Med. 2008; (44): 19-25.

18. Herzyk A, Kądzielawa D. [red.] Związek mózg-zachowanie w ujęciu neuropsychologii klinicznej. Lublin; Wydawnictwo UMCS 1997.

19. Siek S. Treningi relaksacyjne. Warszawa. ATK 1990.

20. Horgan J. The Myth of Mind Control: Will anyone ever decode the human brain? 2004; 25 (10). 
21. Horgan J. The Forgotten Era of Brain Chips. Scientific American 2005; 293 (4): 66-73.

22. Botwina R, Starosta W. Mentalne wspomaganie sportowców - teoria i praktyka. Me-dycyna Sportowa 2002; 12.

23. Klimkowski M., Herzyk A. [red.]. Neuropsychologia kliniczna. Wybrane zagadnienia. Lublin; Wydawnictwo UMCS 1994.

24. Walsh K. Neuropsychologia kliniczna. Warszawa; PWN 1998.

25. Springer SP, Deutsch G. Lewy mózg, prawy mózg z perspektywy neurobiologii po-znawczej. Warszawa; Prószyński i S-ka 2004.

26. Seligman M. Authentic happiness: Using the new positive psychology to realize your potential for lasting fulfilment. New York; Free Press 2002.

27. Delgado JM. Instrumentation, working hypotheses and clinical aspects of neurostimulation. Applied Neurophysiology 1977/1978; (40): 2-4; 88-110.
28. Raymond J, Said I, Parkinson LA, Gruzelier JH. Biofeedback and dance performance: a preliminary investigation. Applied Psychophysiology and Biofeedback 2005; 30 (1): $65-74$

29. Isen AM. Rola neuropsychologii w zrozumieniu korzystnego wpływu afektu pozy-tywnego na zachowania społeczne i procesy poznawcze. [w:] Czapiński J. [red.] Psychologia pozytywna. Nauka o szczęściu, zdrowiu, sile i cnotach człowieka. Warszawa; PWN 2004: 284-302.

30. Bradley R, McCraty R, Atkinson M, Tomasino D, Daugherty A, Arguelles L. Emo-tion self-regulation, psychophysiological coherence and test anxiety: results from an experiment using electrophysiological measures. Apl. Psychophysiol. Biofeedback 2010; 35 (4): 261-83. 